\title{
UPAYA PENCEGAHAN PLAGIARISME DENGAN MENGGUNAKAN APLIKASI MENDELEY DALAM MELAKUKAN PENULISAN SITASI DAN REFERENSI
}

\author{
Nila Puspita Sari'1), Lenny Nofriyani Adam¹) \\ 1)Program Studi Pendidikan Bahasa dan Sastra Indonesia, Universitas Timor, Kefamenanu, NTT, Indonesia \\ Corresponding author : Nila Puspita Sari \\ Email: nilapuspita@unimor.ac.id
}

Diterima 25 Januari 2021, Direvisi 23 April 2021, Disetujui 24 April 2021

\begin{abstract}
ABSTRAK
Menulis skripsi masih menjadi salah satu syarat mahasiswa untuk memperoleh gelar sarjana. Tujuan pelaksanaan kegiatan pengabdian ini adalah memberikan sosialisai terkait plagiarisme serta penulisan sitasi dan daftar pustaka kepada mahasiswa yang sedang menulis karya ilmiah sebagai tugas akhir untuk mencegah plagiarisme utamaya self-plagiarism. Kegiatan ini dilakukan di STIPAS St. Petrus Keuskupan Atambua, Kefamenanu yang dihadiri oleh 20 orang peserta yakni mahasiswa semester akhir yang sedang menulis tugas akhir. Kegiatan ini dilakukan dengan dua tahap, pertama pemberian angket terkait pemahaman peserta tentang aplikasi Mendeley dan plagiarism. Kegiatan kemudian dilanjukan dengan pemberian materi terkait plagiarism dan aplikasi Mendeley. Selanjutnya, peserta diajarkan cara menggunakan aplikasi Mendeley, mulai dari penginstalan hingga pada bagaimana pengaplikasian Mendeley dalam membuat referensi. Kegiatan kemudian diakhiri dengan pemberian angket terkaut kepuasan pelaksanaan kegiatan oleh peserta dan pemahaman peserta terkait aplikasi Mendeley setelah dilakukan pelatihan. Mahasiswa lebih sadar dalam melakukan sitasi dan juga penulisan referensi untuk menghindari plagiarism khususnya self-plagiarism dalam penulisan tugas akhir mereka. Peserta juga sangat antusias dengan penggunaan aplikasi Mendeley dalam menulis daftar referensi. Berdasarkan hal tersebut, pemahaman terkait isu-isu plagiarisme kaitannya dengan penulisan kutipan dan daftar pustaka perlu ditingkatkan lagi untuk mencegah bertambahnya perilaku plagiarisme. Selanjutnya, pendampingan lebih lanjut juga dilakukan kepada peserta baik secara langsung maupun melalui grup chatingan WhatssUp.
\end{abstract}

Kata Kunci: plagiarisme; sitasi; mendeley.

\begin{abstract}
Writing a thesis is still one of the requirements for students to obtain a bachelor's degree. This activity aims at giving material related to plagiarism also about citation and references to the final grade students who are writing their thesis to avoid plagiarism, particularly self-plagiarism. This activity has been conducted in STIPAS St. Petrus Keuskupan Atambua, Kefamenanu, that was attended by 20 students. It was conducted by two steps, firstly by spreading questionnaire related to students' understanding about Mendeley and plagiarism. It was also continued to give material about Mendeley and plagiarism. Besides, the students also were taught about using that application started by installing till applying in making references. This activity was ended by spreading questionnaire secondly related their satisfaction about this activity and also their understanding about material has been presented. There are more aware in citation and writing references to avoid plagiarism particularly self-plagiarism in their thesis. Besides, the students are also enthusiastic in making references using Mendeley. Based on that case, students understanding related to plagiarism issues in relation to citation and references is suggested to be improved to avoid plagiarist. For the next part, accompanying the students in applying those things are still conducting directly or by WhatssUp.
\end{abstract}

Keywords: plagiarism; citation; Mendeley.

\section{PENDAHULUAN}

Penelitian sebagai salah kewajiban bagi sivitas akademika perguruan tinggi, baik dosen maupun mahasiswa menuntut keduanya untuk dapat mewujudkan suatu karya laporan hasil penelitian yang telah dilakukan. Penulisan laporan hasil penelitian merupakan bagian penting, disamping sebagai pembuktian akan akhir penelitian juga merupakan kewajiban bagi peneliti utamanya mahasiswa yang harus melaporkan hasil penelitian sebagai tugas akhir

Menulis skripsi masih menjadi salah satu syarat mahasiswa untuk memperoleh gelar sarjana. Namun, terlebih dahulu mari pahami apa itu menulis. (Rosmini Silaban, 2017) Menulis merupakan kegiatan menggali pikiran 
dan perasaan mengenai suatu subjek, memilih hal-hal yang akan ditulis, menentukan cara menuliskannya sehingga pembaca dapat memahaminya dengan mudah dan jelas. Dengan demikian, kemampuan menulis juga sangat penting untuk diperhatikan kaitannya dengan penulisan tugas akhir. Tidak sekedar melakukan penelitian dan analisis dengan menerapkan ilmu yang sudah dipelajari, mahasiswa harus mampu melaporkan hasil penelitian mereka dengan menuangkan dalam bentuk tulisan akhir.

Berkaitan dengan hal tersebut, menulis skripsi harus mempertimbangkan banyak hal termasuk isu plagiarisme. Hal ini berdasarkan pertimbangan bahwa karangan ilmiah akan banyak mengambil rujukan sebagai bahan referensi, sehingga kurang teliti dalam pengutipan bias jadi penulis akan masuk pada jurang plagiarism baik sengaja maupun tidak sengaja, (Herqutanto, 2013) menyebutkan bahwa plagiarisme berasal dari bahasa Latin yakni plagiari(us) yang berarti penculik dan plagium yang berarti plagi(um) yang berarti menculik. Dalam tulisannya, (Herqutanto, 2013) juga menambahkan bahwa di dunia akademik, kadang terjadi plagiarisme oleh karena beban yang diterima peserta didik amat berlebihan dan tidak sesuai dengan waktu yang tersedia, sehingga terjadilah "gunting tempel" apalagi bila penulis yang dalam hal ini peserta didik tidak mengetahui cara melakukan sitasi/perujukan dengan benar. Tugas kelompok juga memicu plagiarisme.

Lebih lanjut, (Shadiqi, 2019) menyebutkan bahwa era paperless dan internet dapat berdampak dalam menumbuhkan perilaku plagiarisme karena orang mudah mengakses karya orang lain. Hal ini menjadi masuk akal bahwa ketika budaya copy paste dari internet menjadi sangat mudah bagi orang yang akan mengambil tulisan orang lain sebagai bahan referensi. Kemudahan itulah yang terkadang dimanfaatkan oleh para oknum untuk menyalin tulisan orang lain tanpa menyebutkan nama pemilik tulisan tersebut. Saat ini, isu plagiarisme juga telah menjadi salah satu pelanggaran etika.

(Wahyuni, 2018) menjelaskan bahwa isu plagiarisme sendiri masuk dalam ranah Kode Etik Akademik atau ketidakjujuran akademis (academic misconduct) (Adesile et al, 2016; Cronan et. al., 2015) berupa cheating, seeking outside help, plagiarism, and electronic cheating. Beberapa penelitian telah dilakukan di berbagai negara dan menunjukkan bahwa perilaku plagiat tersebut dapat muncul karena faktor kebiasaan. Lebih lanut, selain menjadi isu pelanggaran etika akademik, plagiarism juga telah menjamah ke ranah hokum. Sebuah referensi konseptual terkait plagiarism dijelaskan dalam Black Law Dictionary dalam (Soelistyo, 2011) dijelaskan bahwa

"The deliberate and knowing presentation of another person's original ideas or creative expression as one's own. Generally, plagiarism is immoral but not illegal. If the expression's creator gives unrestricted permission for its use and the user claim the expression as original, the user commits plagiarism but does not violate copyright laws. If the original expression is copied without permission, the plagiarist may violate copyright laws, even if credit goes to the creator. And if the plagiarism results in material gain, it may be deemed a passing-off activity that violates the Lanham Act"

Meskipun definisi tersebut didefinisikan dari perspektif hokum, tetap saja pada hakekatnya lagiarisme merupakan tindakan mengutip karya orang lain dan tentunya hal tersebut melanggar hak cipta. Berkaitan dengan plagiarism, terkadang secara tidak sadar dilakukan karena kurang teliti terhadap kutipan yang telah dilakukan, lebih parahnya lagi, playing disebut dengan plagiarism terhadap diri sendri. Dalam penulisan karya ilmiah, pengutipan merupakan hal yang sangat perlu serta sangat membantu terlebih hal yang berkaitan dengan isu-isu terbaru yang dapat mendukung argument hasil penelitian, dengan demikian sangat ditekankan penulis memperhatikan ketika menulis sitasi atau kutipan agar terhindar dari catatan plagiarisme.

Merujuk pada KBBI edisi V, sitasi berarti kutipan. Sulistiyo-Basuki (1998) dalam (Ilham, 1998)(Istiana, 2013) juga mendefinisikan sitasi sebagai analisis sitiran digunakan untuk mengukur pengaruh intelektual ilmuwan dari pengarang yang disitir, karena beberapa studi sitiran literatur digunakan untuk mengetahui karakteristik komunikasi ilmu pengetahuan dan banyak aspek kualitatif dari penelitian dan publikasi. Sitasi merupakan istilah yang sangat familiar bagi para akademisi, dimana dalam kaitannya dengan penulisan karya ilmiah, mengutip ide maupun teori orang lain merupakan salah satu bagiannya. Di sisi lain, (Mufid, 2015) juga menambahkan bahwa sitasi terdiri dari dua bagian utama, yakni mengutip karya yang relevan dengan topik yang ditulis dan membuat daftar pustaka.

Lebih lanjut, (Surachman, 2016) menambahkan bahwa sitiran atau kutipan tidak saja penting sebagai bentuk informasi kepada sumber aslinya, akan tetapi lebih pada bagaimana pengembangan pengetahuan itu dibangun melalui tulisan-tulisan yang saling terkait.. Oleh sebab itu, pemahaman terkait 
dengan sitasi baik itu jenis maupun cara melakukan sitasi bahkan sanksi akan kesalahan dalam sitasi menjadi mutlak bagi para akademisi. Betapa tidak, sanksi akan kesalahan sitasi yang biasanya mengarah pada plagiarism sangat ketat ditegakkan. Dengan demikian, menghindari plagiarisme dapat dilakukan salah satunya dengan melakukan sitasi yang baik dan benar.

Bagian dari upaya untuk menghindari plagiarisme adalah dengan memahami berbagai model sitasi, cara membuat sitasi (kutipan) dan menuliskan daftar pustaka. PeSngetahuan ini penting, ketika kita akan membuat suatu karya ilmiah. Menuliskan sitasi (kutipan) merupakan bentuk pengakuan terhadap pengarang, karena ide, gagasan, pendapat atau bahkan teorinya telah kita gunakan, untuk mendukung atau melengkapi pendapat, ide kita dalam sebuah karya tertentu (Istiana, 2013).

Berdasarkan hal tersebut, dapatlah dipahami bahwa sitasi sangat erat kaitannya dengan plagiarisme, karena dengan melakukan sitasi yang benar berimplikasi pada pengakuan terhadap karya orang lain yang akan menjauhkan para akademisi dari sematan plagiator. Beberapa hal yang perlu diketahui kaitannya dengan sitasi adalah jenis dan cara melakukan sitasi. Berkaitan dengan jenisnya, terdapat beberapa model yang diistilahkan style dalam melakukan sitasi, diantaranya yang paling umum digunakan adalah sebagai berikut:

1. APA (American Psychological Association) Style

2. MLA (Modern Language Association) Style

3. CHICAGO Dan TURABIAN Style

4. AMA (American Medical Association) Style

5. IEEE (Institute of Electrical and Electronics Engineers) Citation Style

Model atau jenis sitasi yang diuraikan tersebut memiliki sistematika penulisan sitasi yang berbeda bergantung model apa yang disepakati oleh suatu lembaga akademik untuk digunakan dalam sitasi dan penulisan daftar pustaka. Penggunaan aplikasi Mendeley juga akan secara otomatis mengikuti model yang dipilih ketika melakukan sitasi dan penulisan daftar pustaka.

Berdasarkan pengalaman, seringkali ditemukan ketidaksesuaian antara isi tulisan mahasiswa, sitasi dan juga penulisan daftar referensi atau daftar pustaka pada tulisan akhir mahasiswa. Hal ini mengindikasikan beberapa hal, yang pertama mahasiswa bisa jadi hanya menyalin kalimat dari buku ataupun tulisan pada orang lain di web yang gampang sekali mereka temukan menggunakan google atau bisa juga mereka belum memahami sepenuhnya tata cara melakukan pengutipan (sitasi) dan juga penulisan referensi dengan baik dan benar.

Fakta tersebut merupakan isu penting dalam dunia pendidikan di perguruan tinggi manakala tulisan mahasiswa bisa saja terindikasi plagiarisme karena mereka tidak melakukan sitasi dan penulisan daftar pustaka dengan benar. Kesalahan dalam sitasi dan penulisan referensi jika dibiarkan maka akan menjadi kebiasaan buruk yang berakibat fatal. Mahasiswa pada umumnya dan terkhususnya yang sedang menulis skripsi harus dibekali dan terus diperkuat pemahamannya tentang tata cara mengutip dan menulis daftar pustaka yang benar bahkan harus pula dijelaskan akibat jika sitasi dilakukan tidak sesuai aturan. Mahasiswa harus memiliki kepekaan terhadap isu plagiarisme dan diberitahu sanksinya agar mereka benar-benar tahu dan berupaya menghindarinya. Penelitian perihal isu-isu plagiarisme telah dilakukan sebelumnya, salah satunya yang dilakukan oleh (Nur, 2019) yang mengkaji hubungan antara persepsi plagiarisme dan kepercayaan pengguna tentangg keakuratan sofware turnitin yang didasari oleh pemahaman bahwa belum adanya ketentuan atau standar tentang plagiarisme memunculkan persepsi yang berbedabeda pada setiap orang terkait plagiarisme.

Lebih lanjut, mengingat pentingnya hal tersebut, penulisan tugas akhir yang baik menjadi salah satu tolak ukur para penulis itu sendiri, baik yang berkaitan dengan sistematika penulisan, isi tulisan maupun penggunaan referensi di dalamnya. Referensi yang berkaitan dengan penggunaan opini-opini para ahli, hasil penelitian-penelitian terdahulu yang digunakan untuk menguatkan pendapat penulis yang dituangkan dalam tulisan merupakan salah satu bagian penting dalam tulisan ilmiah. Oleh sebab itu, pengutipan juga memiliki cara dalam penggunaan dan penulisannya.

Berkaitan dengan hal tersebut, menyusul era revolusi industry 4.0 dengan gencarnya pemanfaatan teknologi dalam setiap kegiatan tak terkecuali bidang akademik, pemanfaatan aplikasi dalam penulisan tugas akhir pun merupakan salah satu bagian dalam menyongsng era itu. Dengan demikian, kegiatan pengabdian ini dilakukan untuk membantu para mahasiswa khusunya yang sedang melakukan penelitian dan penulisan tugas akhir dalam memanfaatkan aplikasi 
Mendeley dalam melakukan sitasi dan penulisan daftar pustaka.

Berdasarkan uraian latar belakang di atas, masalah yang diangkat dalam kegiatan ini adalah: 1) Bagaimana pemahaman mahasiswa mengenai plagiarisme?, 2) Bagaimana mahasiswa melakukan penulisan sitasi dan daftar referensi?, 3) Apakah menulis sitasi dan daftar referensi dengan menggunakan aplikasi lebih efektif?

\section{METODE}

Kegiatan ini dilakukan di STIPAS St. Petrus Keuskupan Atamabua, Kefamenanu yang dihadiri oleh 20 orang peserta yakni mahasiswa semester akhir yang sedang menulis tugas akhir Adapun metode yang digunakan dalam kegiatan ini adalah pemberian angket, ceramah, tanya jawab dan praktek. Pemberian angket dilakukan sebanyak dua kali sebelum dan sesudah pelaksanaan kegiatan. Angket pertama memuat pertanyaan terkait pemahaman mahasiswa sebagai peserta pelatihan terhadap plagiarisme, sitasi dan aplikasi penulisan daftar referensi. Selanjutnya dilakukan ceramah dan tanya jawab ketika melakukan sosialisasi tentang plagiarisme, sitasi dan aplikasi mendeley. Materi yang diberikan berkaitan dengan plagiarisme, bagaimana teridentifikasi sebagai plagiator serta etika pengutipan untuk menghindari plagiarisme; menulis sitasi dan daftar referensi serta pengenalan aplikasi Mendeley.

Selanjutnya, para peserta dibimbing dalam melakukan penginstalan aplikasi Mendeley yang dilanjutkan dengan tutorial penggunaan aplikasi. Setelah penginstalan selesai, salah satu peserta yang telah membawa tulisan diminta untuk menjadi contoh dalam menulis sitasi serta membuat daftar referensi dengan menggunakan aplikasi Mendeley. Semua peserta kemudian dibimbing untuk menggunakan aplikasi tersebut dalam menulis sitasi dan daftar referensi. Setelah pelatihan selesai, peserta kemudian diminta untuk mengisi angket terkait kepuasan peserta terhadap pelatihan ini serta tanggapannya terhadap aplikasi Mendeley dalam menulis sitasi dan daftar referensi. Pelatihan ini berlanjut pada pendampingan peserta dalam menulis tugas akhir mereka karena sejak awal dipilih peserta pelatihan yang merupakan mahasiswa semester akhir yang sedang dalam proses bimbingan tugas akhir.

\section{HASIL DAN PEMBAHASAN}

Sosialisasi terkait plagiarisme kaitannya dengan penulisan sitasi dan daftar pustaka yang telah dilakukan memberikan pemahaman baru kepada para peserta akan beberapa jenis sitasi, bagaimana melakukan sitasi yang baik dan benar serta sanksi yang dapat ditimbulkan jika terjadi kesalahan dalam sitasi serta hal-hal yang trekait dengan isu plagiarisme. Beberapa jenis sitasi yang telah dipaparkan, sitasi terhadap diri sendiri merupakan informasi baru bagi para peserta, dimana awalnya mereka beranggapan bahwa mengutip tulisan sendiri tidak seyogyanya juga mencantumkan nama dalam daftar pustaka. Selain itu, para peserta juga mendapatkan informasi baru berdasarkan angket terkait plagiarisme yang merupakan salah satu dampak ketika melakukan kesalahan dalam melakukan sitasi. Terlebih lagi, plagiarisme diri sendiri atau yang akrab dikenal dengan istilah self-plagiarism menjadi salah satu hal yang menarik perhatian para peserta.

Analisis angket awal terkait pemahaman mahasiswa terhadap plagiarism dan aplikasi Mendeley menunjukkan bahwa pemahaman berada pada level rendah dengan persentase hasil analisis sebesar $45 \%$ dalam rata-rata. Berdasarkan butir pertanyaan dalam angket, pemahaman yang paling rendah rata-rata ditunjukkan terkait dengan definisi serta jenisjenis sitasi. Lebih lanjut, terkait aplikasi Mendeley, respon sebagian peserta yang hadir menunjukkan mereka baru mendengar terkait aplikasi tersebut.

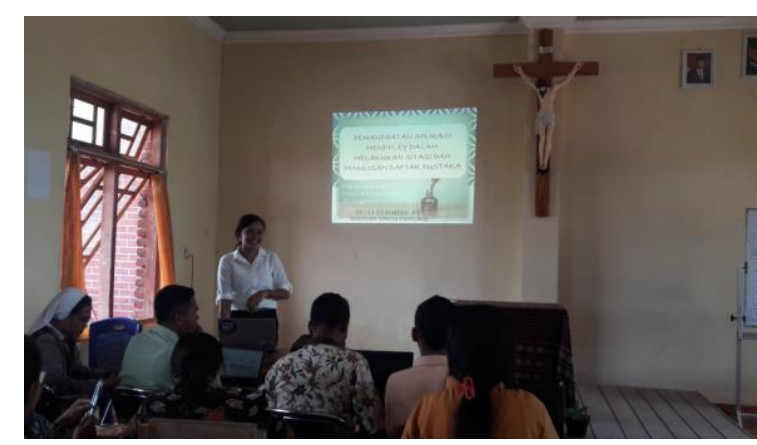

Gambar 1: Penyebaran angket

Terkait dengan sosialisai, hal ini dilakukan dengan dua tahap. Pertama, pemberian materi awal terkait dengan plagiarisme, sitasi dan pentingnya referensi dalam penulisan karya ilmiah. Pemberian materi selanjutnya terkait aplikasi Mendeley. Materi terkait ini disampaikan secara bersamaan dengan tutorial penggunaan aplikasi Mendeley. Pada tahap ini, mahasiswa diajarkan secara langsung mulai dari penginstalan aplikasi hingga pada penggunaan aplikasi pada naskah yang akan menggunakan sitasi dan referensi dengan menggunakan aplikasi Mendeley. 


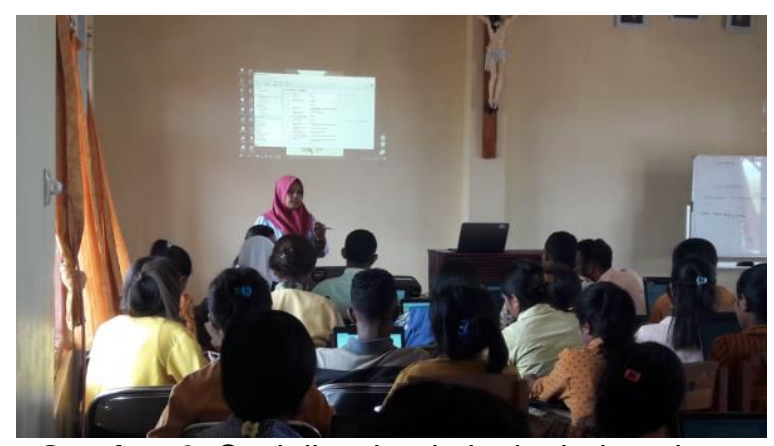

Gambar 2: Sosialisasi terkait plagiarism dan Mendeley

Terkait dengan angket akhir setelah pemberian materi, berbading terbalik dengan hasil angket sebelumnya, hasil analisis angket kedua terkait kepuasan dan pemahaman mahasiswa terkait materi yang diberikan setelah sosialisasi menunjukkan peningkatan yang signifikan sebesar $33 \%$ dengan rata-rata respon sebesar 78\%. Peningkatan pengetahuan yang signifikan berkaitan dengan jenis-jenis sitasi serta jenis referensi yang dapat dijadikan acuan dalam menulis karya ilmiah, dimana sebelumnya para peserta hanya memahami bahwa sumber acuan dalam penulisan karya ilmiah hanyalah buku cetak. Sebagian besar mahasiswa juga tidak familiar dengan istilah artikel jurnal dan bagaimana menggunakan artikel jurnal sebagai sumber rujukan. Oleh sebab itu, dengan meeberikan pelatihan tentang penggunaan aplikasi Mendeley dalam pengutipan dan penulisan daftar pustaka, para peserta merasa sangat terbantu dengan hal tersebut.

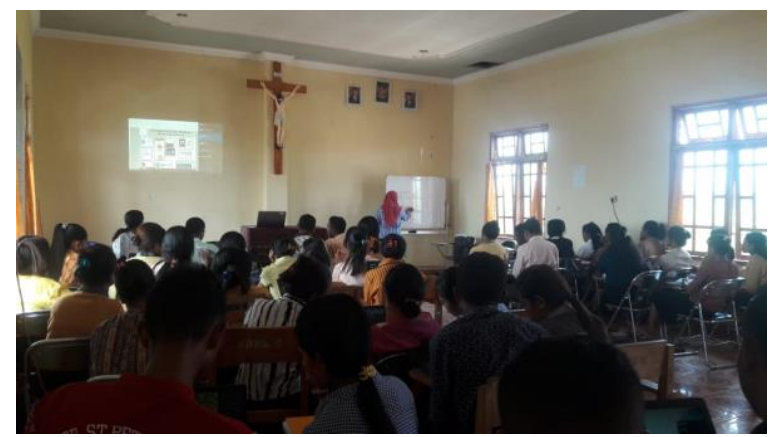

Gambar 3: Tutorial terkait aplikasi Mendeley (penginstalan hingga penggunaan aplikasi dalam sitasi)

Berdasarkan hal tersebut pemahaman tentang sumber-sumber yang dapat dijadikan acuan dalam penulisan karya ilmiah kepada para mahasiswa sangat perlu ditingkatkan lagi dimana pendampingan harus terus dilakukan.

\section{SIMPULAN DAN SARAN \\ Simpulan}

Setelah melakukan analisis angket terkait pemahaman peserta tentang plagiarisme dan penulisan sitasi dan daftar pustaka dengan menggunakan aplikasi Mendeley sebelum dan sesudah dilakukannya sosialisasi menunjukkan peningkatan yang signifikan bagi seluruh peserta, utamanya hal yang berkaitan dengan self-plagiarism dan jenis sitasi serta referensi yang bisa digunakan dalam penulisan karya ilmiah. Peserta juga sangat antusias dengan penggunaan aplikasi Mendeley dalam menulis daftar referensi.

\section{Saran}

Berdasarkan hal yang diuraikan dalam simpulan, sangat perlu kiranya bagi para dosen untuk terus memberikan bimbingan kepada para mahasiswa terkait plagiarisme dan sitasi tentang cara serta dampaknya, juga kemudahan yang akan diberikan ketika mereka melakukan sitasi dan penulisan daftar pustaka dengan menggunakan aplikasi. Selain itu, karena keterbatasan ruang dan waktu, sosialisasi terkait sitasi, penulisan daftar pustaka serta aplikasi yang dapat membantu hal tersebut sangat perlu untuk sering dilakukan mengingat dampak yang akan diperoleh bila terjadi kesalahan dalam melakukan sitasi.

\section{DAFTAR RUJUKAN}

Herqutanto, H. (2013). Plagiarisme, Runtuhnya Tembok Kejujuran Akademik. EJournal Kedokteran Indonesia, 1(1), 1-3. https://doi.org/10.23886/ejki.1.1589.1-3

Ilham. (1998). Apa itu sitasi. In Apa itu sitasi (pp. 1-9). https://osf.io/preprints/inarxiv/kebt3/

Istiana, P. (2013). Membuat Sitasi dan Daftar Pustaka. ResearchGate, May 2013. https://www.researchgate.net/publication/ 270050381_Membuat_Sitasi_dan_Daftar Pustaka

Mufid, M. (2015). Pedoman Sitasi dalam Penulisan Karya Tulis: Penulisan Karya Tulis Dalam Modern Language Association (MLA) Style. 1-9. http://repository.uin-malang.ac.id/465/

Nur, A. S. (2019). HUBUNGAN ANTARA PERSEPSI PLAGIARISME DENGAN KEPERCAYAAN PENGGUNA TENTANG KEAKURATAN SOFTWARE TURNITIN DI UNIVERSITAS INDONESIA Oleh: Sofia Nur Aisyah 1. Universitas Airlangga Repository.

Rosmini Silaban. (2017). Upaya Peningkatan Kemampuan Menulis Metode Latihan Siswa Kelas 1 SD Negeri 014 Pagaran Tapah Darusalam. Jurnal Pendidikan Dan Pengajaran, 1, 16-24. 
Shadiqi, M. A. (2019). Memahami dan Mencegah Perilaku Plagiarisme dalam Menulis Karya IImiah. Buletin Psikologi, 27(1), 30. https://doi.org/10.22146/buletinpsikologi.4 3058

Soelistyo, H. (2011). Plagiarisme : pelanggaran hak cipta dan etika.

Surachman, A. (2016). Panduan Gaya Penulisan Sitiran Karya IImiah. In Panduan Gaya Penulisan Sitiran Karya IImiah (pp. 1-12). lib.ugm.ac.id

Wahyuni, N. C. (2018). Ketika Plagiarisme adalah Suatu Permasalahan Etika. Record and Library Journal, 4(1), 8-14. https://e-

journal.unair.ac.id/RLJ/article/view/8751/ 5813 